\title{
Finding Ancient Coins: An Early Numismatic Study on the Spread of Islam from Arab to the Nusantara
}

\author{
Nurman Kholis ${ }^{1 *}$, Kamal Yusuf ${ }^{2}$, Asep Saefullah ${ }^{3}$, Muhammad Rais $^{4}$, \\ Ali Akbar ${ }^{5}$, Masmedia Pinem ${ }^{6}$, Dede Burhanuddin ${ }^{7}$ \\ ${ }^{l}$ National Research and Innovation Agency Republic of Indonesia, Indonesia \\ ${ }^{2}$ UIN Sunan Ampel Surabaya, Indonesia \\ ${ }^{3}$ National Research and Innovation Agency Republic of Indonesia, Indonesia \\ ${ }^{4}$ STAIN Majene, Indonesia \\ ${ }^{5}$ National Research and Innovation Agency Republic of Indonesia, Indonesia \\ ${ }^{6}$ National Research and Innovation Agency Republic of Indonesia, Indonesia \\ ${ }^{7}$ National Research and Innovation Agency Republic of Indonesia, Indonesia \\ *Corresponding author: nurmankholis@gmail.com
}

\begin{abstract}
The current research is aimed to trace and find out the ancient coins from Arabic found in the archipelago and their relation to literacy related to the history of the Islamization process and the accelerated development of Islamic civilization in this region. As a preliminary study, this research was conducted with an exploratory approach intended to collect data for the first stage in the historical research method, namely heuristics. Focus Group Discussion (FGD), observation, and interviews with various relevant stakeholders were conducted to collect the data. The assumption of this study was based on tentative findings of Ery Soedewo and Ichwan Azhari. The ancient coins found in Nusantara are Dirham (silver coins) from the Sasanid Empire with the Persian-Majusi symbol from the 7th century found in North Sumatra. In this area, dirhams with Arabic-Islamic inscriptions during the Umayyad Caliphate in the 7th and 8th centuries are also found. They were still produced during the Abbasid Caliphate to the 10th century. Some of the coins are stored in the North Sumatra Money Museum, The Museum of Quranic History in Medan, and a collector in Palembang, South Sumatra. This Finding correlated with Buya Hamka's notion of Islam's advent in the archipelago beginning in the first century of Hegira (seventh century AD). Michael Flecher's research on the Belitung Wreck site comes from the eighth century AD, estimated shipped from Arabia. The result indicates that The trading activities influenced Islamic spread in Indonesia from Arab to Indonesia. The coins as a means of exchange also coined the most fundamental Islamic principle, tauhid.
\end{abstract}

Keywords: ancient coins, Arab, Islam, numismatics, heuristics.

\section{INTRODUCTION}

Covid-19, which has wreaked havoc throughout the world, has piqued the interest of academics to investigate the phenomenon. For example, Haryanto from the Ministry of National Planning (Bappenas) of the Republic of Indonesia approached the issue from a monetary viewpoint. As a result, Indonesia's pandemic cases climbed by one percent between March 2 and April 2020, according to his research based on daily data on Covid-19 cases from March 2 to April 2020. Additionally, the depreciation of the Rupiah concerning the US dollar increased by 0.02 percent due to these developments (Haryanto, 2020). So one US dollar is presently worth around IDR 15,000 at the current exchange rate. It demonstrated the growing disparity between now and 1946 when one USD was equal to one IDR.

A significant portion of the Rupiah's depreciation versus the US dollar is increasingly attributed to digital or electronic currencies rather than tiny pieces of paper used as money in the traditional sense. Yuval Noah Harari, a history professor at the Hebrew University of 
Israel's Department of History, made this claim in a recent interview. According to him, coins and paper money are becoming increasingly scarce forms of money. Thus, whereas the entire quantity of money in the world is around $\$ 60$ trillion, the total number of coins and banknotes is less than $\$ 6$ trillion in total. On the other hand, computer systems hold more than $\$ 50$ trillion in accounts, accounting for more than 90 percent of all money in existence today. In a similar vein, commercial transactions are carried out by transferring electronic data from one computer file to another rather than through the exchange of actual money [3].

As many paper money changes into electronic money, the existence of ancient coins can be increasingly ignored by the current generation. They do not think of these ancient coins as a source of historical writing. Muhammad Atho Mudzhar, the head of research and development and education and training of the Ministry of Religion (2001-2010), stated that the history of the entry and development of Islam from Arabia to the archipelago, specifically in a numismatic perspective (the science of money) had not been made yet. The idea of this Professor of UIN Syarif Hidayatullah Jakarta can be realized in connection with the findings of Ery Soedewo (researcher of the Archeology Center of North Sumatra) and Ichwan Azhari (History of the State University of Medan) with their team in the form of ancient coins with Islamic Arabic inscriptions from the 8th century in North Sumatra.

Ancient coins inscribed with Islamic Arabic from the 8th century in North Sumatra, which Ery Soedewo and his team discovered, are considered as one of the initial data for this research and which were only seen through photographs, can be one of the factors contributing to inaccuracies in reading the inscriptions and symbols on these coins. Thus, this present research focuses on the numismatic study.

The numismatic study is what is behind the coins, through its description to the following history [9]. Bates even argues that the design of coins reflects the cultural tradition rather than society's attitudes [10]. For example, coins in Islam have represented the significance of the Islamic political system since the beginning [11]. Further, coins even stand for political legitimation and state power [12]. Moreover, in Middle Ages, the government implicitly asserted the propaganda through coins since they stood for a symbol of legitimacy [13]. Thus, the function of the coin is conserving sacred institutions and becoming administrative and fiscal media [14].
In this present research, the researchers look at the significance of some of these coins' inscriptions or symbols by looking at them directly to be understood more fully. The researcher compares these coins with comparable coins and their descriptions, either directly found in physical form or the form of pictures found in other areas. It is necessary to compare them with similar coins and their descriptions.

\section{METHOD}

This study is conducted within qualitative research techniques, with a numismatic approach as a starting point, and is preliminary. As a preliminary study, this research generates heuristic data, which is the first stage of the historical writing method [5]. As a result, to gather primary data, it is necessary to investigate old Arabic coins from pre- and early-Islamic eras in Indonesia using information from museums, other organizations, historians, archaeologists, and coin collectors, among other sources. The coin collectors who provided the information for this study were located in three locations: (1) North Sumatra, (2) South Sumatra, and (3) Central Java. The coins and their descriptions are then checked with secondary data, found in the form of photographs of comparable ancient coins from museums or collectors in Indonesia or elsewhere and in publications or on the internet to determine their authenticity.

\section{FINDINGS AND DISCUSSION}

\subsection{Findings}

To uncover ancient coins from Arabia in the archipelago so that they can be identified in this initial study, the Center for Research and Development for Literature, Religious Treasures, and Organizational Management of The Research and Development and Training Agency of The Ministry of Religion (Puslitbang LKKMO Badan Litbang dan Diklat Kementerian Agama) team started by conducting a Focus Group Discussion (FGD) on August 6, 2020, in Medan, North Sumatra. Safaruddin Barus from the Medan Money Museum and presentations from two speakers, namely Ery Soedewo (Researcher from the Medan Archaeological Center) and Ichwan Azhari (Historian of the State University of Medan), gave this event an introduction by Safaruddin Barus from the Medan Money Museum and presentations from two speakers, namely Ery Soedewo (Researcher from the Medan Archaeological Center) and Ichwan Azhari (Historian of State University of Medan).

Regarding the preliminary findings and preliminary discussions, Ery Soedewo gave a 
presentation titled "Coins of the Islamic State in North Sumatra: Recent Evidence of Interaction of Archipelago Civilization with the Center for World Islamic Civilization in the VIII M - XI M centuries" (Coins of the Islamic State in North Sumatra: Recent Evidence of Interaction of Archipelago Civilization with the Center for World Islamic Civilization in the VIII M - XI. According to him, the coins were discovered in a quarry near Sibolga at a depth of around 5 (five) meters below the ground's surface. Also discussed were the findings of his team's reading, one of which was Nur Ahmad's reading of ancient coins discovered at the site, as seen in the accompanying photographs.

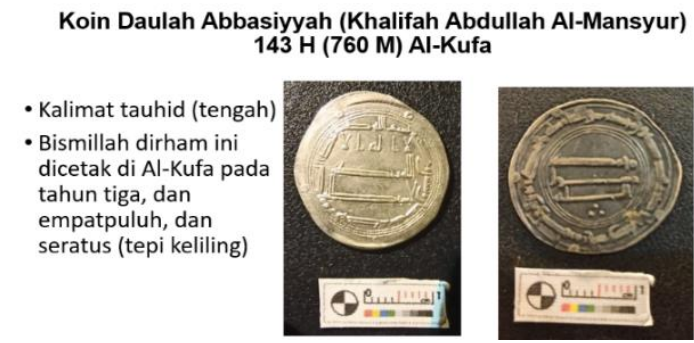

Figure 1 Daulah Abbasiyyah coin $143 \mathrm{H}$

Koin Daulah Abbasiyyah (Khalifah Abdullah Al-Mansur) 147 H (764 M)

- Kalimat tauhid (tengah)

- Bismillah dirham ini dicetak di Al-Rayy pada

tahun tujuh, dan

empatpuluh, dan

seratus (tepi keliling)
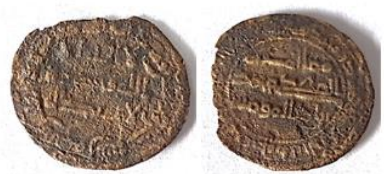

Figure 2 Daulah Abbasiyyah coin $147 \mathrm{H}$

Koin Daulah Abbasiyyah (Khalifah Abdullah Al-Mansur) 149 H (766 - $767 \mathrm{M})$
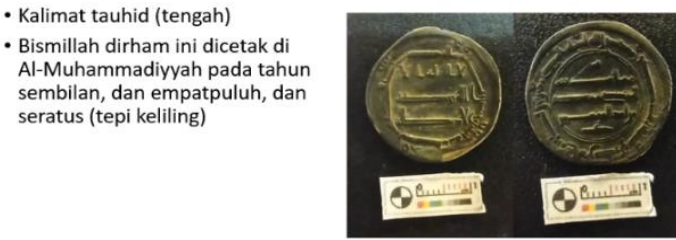

Figure 3 Daulah Abbasiyyah coin $149 \mathrm{H}$

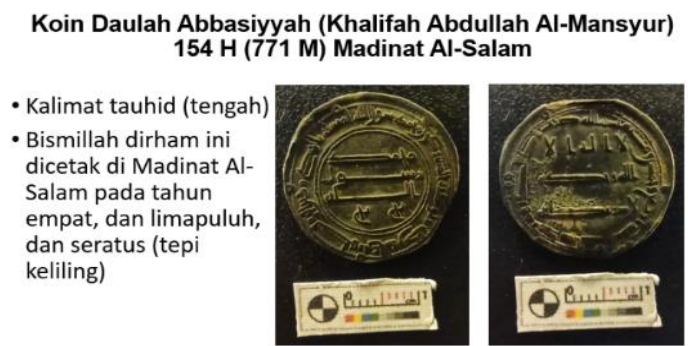

Figure 4 Daulah Abbasiyyah coin $154 \mathrm{H}$

\section{Koin Daulah Abbasiyyah (Khalifah Muhammad Al-Mahdi) $166 \mathrm{H}(782 \mathrm{M})$}

\footnotetext{
- Kalimat tauhid (tengah)

- Bismillah dirham ini dicetak di Al-

Muhammadiyya pada tahun enam, dan

enampuluh, dan seratus (tepi keliling)
}

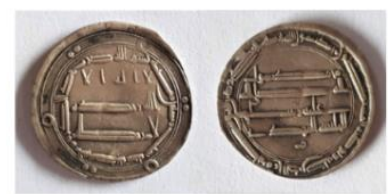

Figure 5 Daulah Abbasiyyah coin $166 \mathrm{H}$

Koin Daulah Abbasiyyah (Khalifah Muhammad Abdullah Al-Amin) $195 \mathrm{H}$ (810 - $811 \mathrm{M})$ Madinat Al-Salam

- Kalimat tauhid (tengah)

- Bismillah dirham ini dicetak Madinat Al-Salam pada tahu lima, dan sembilanpuluh, dan seratus (tepi keliling)

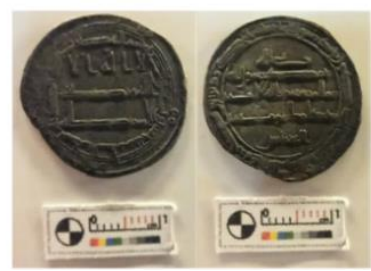

Figure 6 Daulah Abbasiyyah coin $195 \mathrm{H}$

\section{Koin Daulah Abbasiyyah (Khalifah Al-Ma'mun) 204 H (819 - 820 M) Al-Muhammadiyyah} - Kalimat tauhid (tengah)
- Bismillah dirham ini dicetak di
Al-Muhammadiyyah pada tahun
empat dan seratus (tepi keliling)

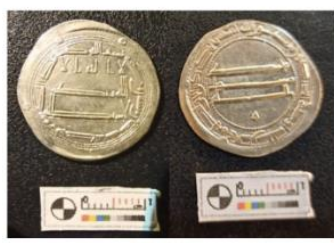

Figure 7 Daulah Abbasiyyah coin $204 \mathrm{H}$

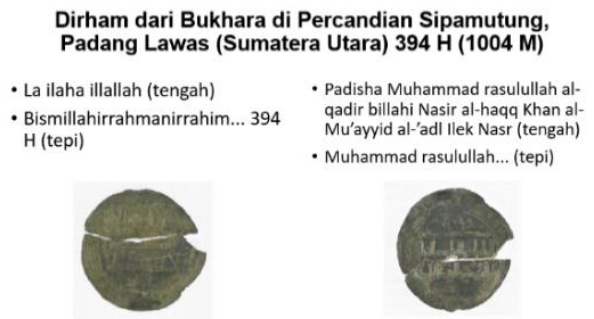

Figure 8 Daulah Abbasiyyah coin $394 \mathrm{H}$ 


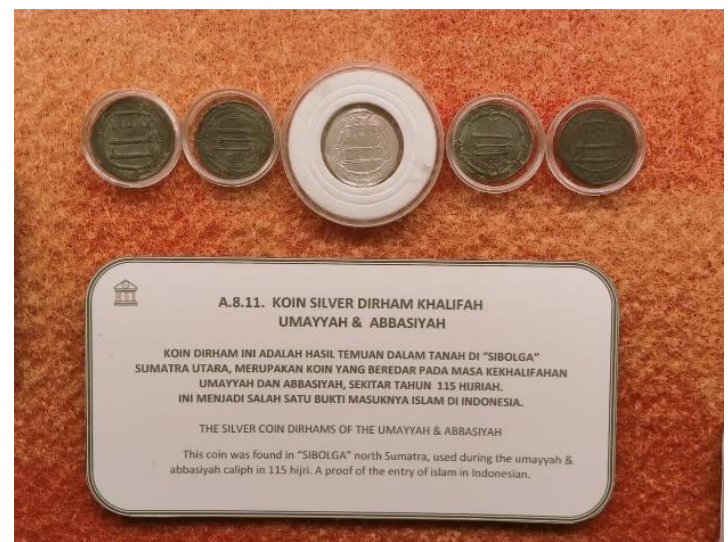

Figure 9 dirhams in the collection of Money Museum in Nort Sumatera

In Sibolga, three dirhams are still being kept in a safe near the excavation site. The remaining five pieces are exhibited at the North Sumatra Money Museum's display case, as shown in the accompanying photo. The museum is open to the public.

Another focal person at the Forum Group Discussion, Ichwan Azhari, also presented tentative findings on coins from the Umayyad and Abbasid periods obtained from residents in Central Tapanuli. These three dirham coins are stored in the Al-Quran History Museum, as seen in the Figure 10.

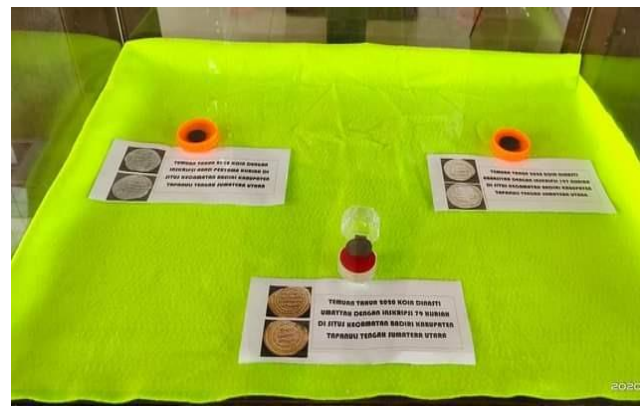

Figure 10 three dirhams collection found in Central Tapanuli

The descriptions of the three coins by Ichwan Azhari and his team are shown in Figure 11-16.

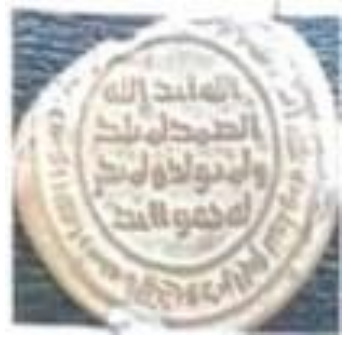

Figure 11. Coin found in Central Tapanuli 1a
The inner circle of the coin has surat al-Ikhlas: "Allahu Ahad, Allahu Shomad, Lam yalid walam yulad, walam yakun lahu kufuwan ahad". The outer circle of the coin is written: "Muhammad Rosulullah, arsalahu bil huda wa dini al-haqqi liyudhirohu'ala addiini kullihi" (taken from Quran Chapter al-Taubah : 33). Size: (weight 2,21 gram, diameter 25,99 $\mathrm{mm}$ ), collection of Museum Sejarah al-Qur'an, North Sumatra, found in Pelabuhan Kuno City, Badiri District, in April 2020.

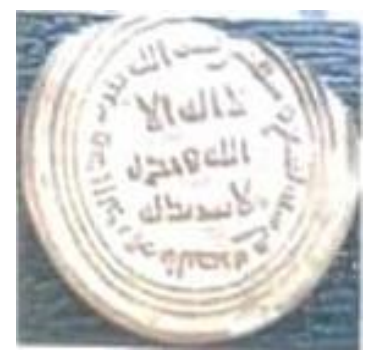

Figure 12 coin found in Central Tapanuli $1 b$

The inner circle is written: "Laa ilaha Illallahu wahdahu la syarikalahu" (means: "There is no god but Allah, The Only One and there is no partner for Him"). The outer circle is written: "Bismillah, Dhuriba addirham bil basrah fi tis'atin wa sab'una (sic.) sanatan"(meaning: "in the name of Allah, this dirham is made in Basrah in $79 \mathrm{H}$ ). Size: (weight 2,21 gram, diameter 25,99 mm), collection of Museum Sejarah alQur'an, North Sumatra, found in Pelabuhan Kuno City, Badiri District, in April 2020

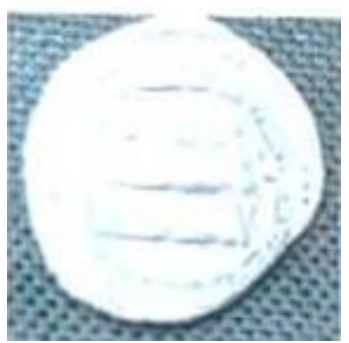

Figure 13 coin found in Central Tapanuli 2a

The inner circle is written: "Laa ilaha Illallah, wahdahu laa syarikalahu" (means: "no gods but Him"). The outer circle is written: "Bismillah, Dhuriba hadza ad-dirham sanah sab'a wa tis'una miatan" (meaning: "in the name of Allah, this dirham is in 197 H). Size: (weight 2,50 gram, diameter 24,93 $\mathrm{mm}$ ), collection of Museum Sejarah al-Qur'an, North Sumatra, found in Pelabuhan Kuno City, Badiri District, in April 2020 


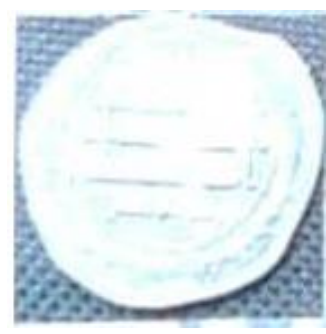

Figure 14 coin found in Central Tapanuli 2b

The inner circle is written: "Laa ilaha Illallah, Dzuirisatin (sic.)". The outer circle is written: "Muhammad Rosulullah, arsalahu bil-huda wa dinil Haqqi liyudhirohu 'ala ad-dini kullihi walau karihal musyrikun. Size : (weight 2,50 gram, diameter 24,93 $\mathrm{mm}$ ), collection of milik Museum Sejarah al-Qur'an, North Sumatra, found in Pelabuhan Kuno City, Badiri District, in April 2020.

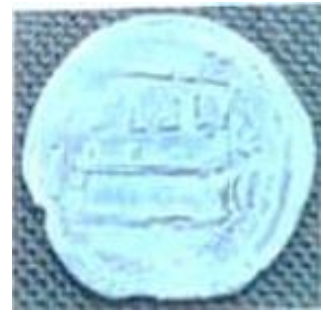

Figure 15 coin found in Central Tapanuli 3a

The inner circle is written: "Laa ilaha Illallah, Dzuriyasatain". The outer circle is written: "Muhammad Rosulullah, arsalahu bi al-huda wadinil Haqqi liyudhirohu 'alad-dini kullihi walau karihal musyrikun. Size : (weight 2,50 gram, diameter 24,93 $\mathrm{mm}$ ), collection of milik Museum Sejarah al-Qur'an, North Sumatra, found in Pelabuhan Kuno City, Badiri District, in April 2020.

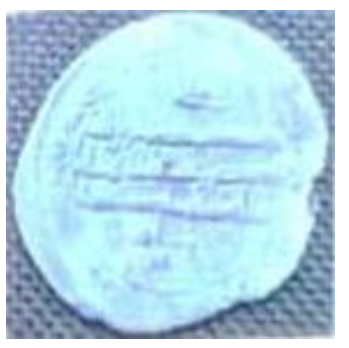

Figure 16 coin found in Central Tapanuli 3b

The inner circle is written: "Ali, Muhammad Rosul Allah, Shollallahu 'alahi wasallam....... (the fourth and fifth lines are not clear and cannot be read, however the coin with "Ali" is usually back to Fatimiyah Caliphate". Size : (weight 2,50 gram, diameter 24,93 $\mathrm{mm}$ ), collection of Museum Sejarah al-Qur'an, North Sumatra, found in Pelabuhan Kuno City, Badiri District, in April 2020.

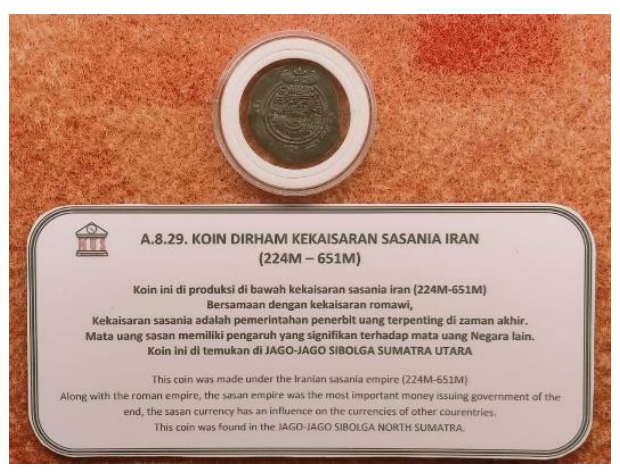

Figure 17 Dirhams from Sasanic found in Sumatera

Besides discovering Arabic coins with the Arabic alphabet from the Umayyad and Abbasid periods, which lasted from the 7th to the 10th century, coins from Persia were discovered in North Sumatra, where they were housed in the Sumatra Money Museum window, as seen in the accompanying image.

The Puslitbang LKKMO Research Team conducted explorations to North Sumatra and six other provinces; South Sumatra, Banten, Jakarta, West Java, Central Java, and South Sulawesi, to determine whether ancient coins from Arabia are also found in other places. In addition, the research team also conducted explorations to find the transformation to local Arabic script coins from the sultanate of the Archipelago. This investigation yielded information that Arab coins discovered in North Sumatra were also circulated to Jakarta, where they were housed at the Fadli Zon Library, and Central Java, where they were housed at the Sultanate Institute, Solo, Central Java. The coins at these two institutions are currently being investigated, particularly inscription.

This exploration also yielded information about ancient Arabian coins discovered in the Musi River in Palembang, South Sumatra, a result of the exploration. However, researchers from other universities have never looked into the currency, according to one collector who goes by the name of Wakjaya. Listed below are some photographs of the coins.
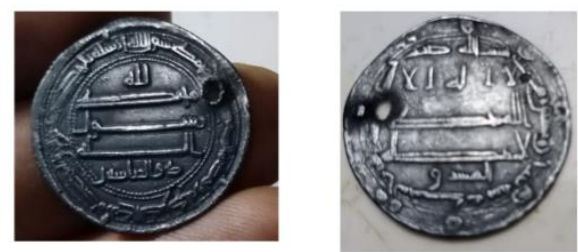

Figure 18 Arabic Coin found in Palembang

A monotheistic sentence "Lā Ilāha Illā Allāh" appears on this dirham coin. The title ذوالرياستنين (Ż̄ al- 
riyāsatain) was given to the prime ministers of the Abbasid Caliphate Government's first generation (132-232 H/750-846 AD). Al-Faḍl bin Sahl, Prime Minister of Al-Ma'mun, is one of them [1].

\subsection{Discussion}

Silver coins discovered in North and South Sumatra date from the 7th to 10th centuries AD and were brought from Arabia. The coins contained Arabic inscriptions such lā ilāha illā Allāh, bismillāh, and other Quranic passages imposed by the Umayyad and Abbasid Caliphate. During the reign of Khusraw II in the seventh century, coins with Persian emblems spread throughout Arabia [6]. Because of the position of the seaports, residents of the archipelago have been in contact with the Arabs since the fourth century AD. An archaeologist from the Bandung Archaeological Center, Lutfi Yondri, discovered seven bones from people who support megalithic civilization at the Bawahparit site in Kototinggi Limapuluhkoto Regency, West Sumatra. According to him, it is one of the cemetery sites in Indonesia that dates from two cultural periods [8]. Both are in the process of transitioning from pre-Islamic burial rituals to Islamic burial norms [8]. Yonder indicated that the results of these bones correlated with Buya Hamka's notion of Islam's advent in the archipelago beginning in the first century of Hegira (seventh century AD). It is based on a textual source from China and a reading of the Chinese calendar system (interview on September 6, 2020). Buya Hamka's notion also correlated with alFaruqi's notion about the map on Arab overseas trade to Archipelago in I/622 [2], and Michael Flecher's research on Belitung Wreck site comes from the eighth century AD. This site is estimated there was a ship from Arabia [7].

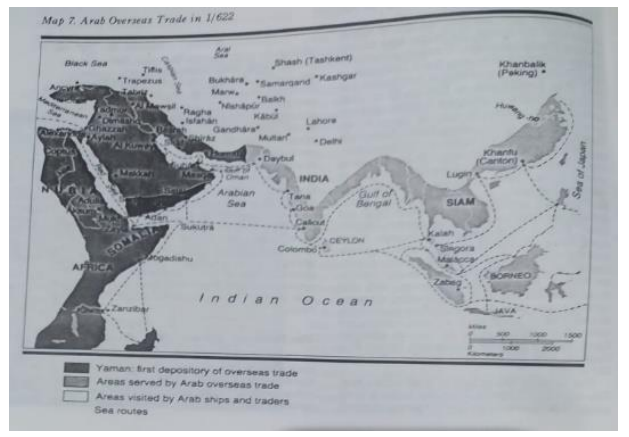

Figure 19 Map on Arab Overseas Trade to Archipelago in I/622 [2]

\section{CONCLUSION}

Ancient coins found in Indonesia especially found and stored in the North Sumatra Money Museum, The Museum of Quranic History in Medan, and Palembang, South Sumatra, indicate that Islamic spread in Indonesia is an impact worldwide trading done by Islamic traders. Moreover, through the coins, tauhid Islamic teaching is also reflected.

\section{REFERENCES}

[1] Al-Ba'lawi, S. M. al-Harafi, Buku Pintar Sejarah Peradaban Islam; Translation from al-Mursyid al-Wajiz fi at-Tarikh wa al-Hadharah alIslamiyah, Pustaka al-Kautsar, Jakarta, 2011.

[2] I. R. Al-Faruqi and L. L. al-Faruqi, The Cultural Atlas of Islam, Macmillan Publishing Company, Newyork, 1986.

[3] Y. N. Harari, Money: Hikayat Uang dan Lahirnya Kaum Rebahan (translation from Money-Vintage Minis, 2018). CV Global Indo Kreatif. Manado, 2020.

[4] Haryanto, "Dampak Covid-19 terhadap Pergerakan Nilai Tukar Rupiah dan Indeks Harga Saham Gabungan (IHSG)", The Indonesian Journal of Development Planning, IV(2) Juni 2020

[5] Kuntowijoyo. Metodologi Sejarah. Tiara Wacana, Yogyakarta, 1994

[6] B. Sodaei, P. M. Khak, and M. Khazaie, "A Study of Sasanian Silver Coins Employing the XRF Technique”, Interdisciplinaria Archeologica: Natural Sciences In Archaeology, IV(2) (2013)

[7] H. O. Sofian, "Nilai Penting Situs Belitung Wreck", Jurnal Arkeologi Siddhayatra, Balai Arkeologi Palembang, Volume 16 No 1 Mei 2011

[8] L. Yondri, S. Bawahparit, "Jejak Penguburan Masa Transisi", Jurnal Lektur Keagamaan Puslitbang LKKMO Badan Litbang dan Diklat Kementerian Agama Vol. 12, No. 2 Desember 2014

[9] J. L. Bacharach, Islamic history through coins: An analysis and catalogue of Tenth-Century 
Ikhshidid coinage. Oxford University Press, 2006

[10] M. Bates, M., "Islamic Numismatics". Review of Middle East Studies, 12(3), 1978, pp 2-18. DOI: $10.1017 / \mathrm{S} 0026318400006568$

[11] Ramadan, "Islamic Numismatic", Journal of Anthropological and Archaeological Science, 2019, pp 33-35, DOI: 10.32474/JAAS.2019.01.000106

[12] A. R. Vardanyan, Islamic Coin Hoards and the Trade Routes: How Dirham Reached the North, Academia.edu, accessed on September 2, 2021, <https://d1 wqtxts1xzle7.cloudfront.net/1242713 1/Talk-with-cover-pagev2.pdf?Expires $=1640649945 \&$ Signature $=\mathrm{Cuc} 1-$ OzDh-

YsQhA259r9plGE8E13b0BjkkPfaRtKH2LThC MS6g0uCAnf41IenkwEoPEw2edLWSbVmbG ZcyYM5nCIRExMbEowOGAhl4uGhtc5zHEG eCZavmTigJPL6qU4gddQgi QcJ1ZLelW1t78 DWcqHiC PxVudMhGOsZA9XVhXiOX GQ AAOsguXBRdwUSPVYiezOGP0Tg8fs6sNmg hH03cJMNkyYb 3SP7JW5PCBUMDUWt5Gt8zRYJMJzThbStMS8mprE QgHOuJUgjxqqJtr5x4F5L6prEhxCKFxvudN3k G2 RbRoaYbeiW KWDIBF3yCUSK $\sim 5 \mathrm{WXH}$ EsQCHObOQ_\&Key-Pair$\underline{\mathrm{Id}=\text { APKAJLOHF5GGSLRB V4ZA }>}$
[13] A. R. Vardanyan, "Christian-Islamic Symbiosis Emerged in Money: Coins As A Tool For Political And Economic Propaganda", Shedet, 2(2), 2015, 23-39.

[14] W. Ziad, "Islamic Coins from a Hindu Temple: Reconsidering Ghaznavid Interactions with Hindu Sacred Sites through New Numismatic Evidence from Gandhara", Journal of the Economic and Social History of the Orient, 2016, 59(4), 618-659. 